\title{
Comparison of IgA-class reticulin and endomysium antibodies in coeliac disease and dermatitis herpetiformis
}

\author{
OLAVI HÄLLSTRÖM
}

From the Department of Clinical Microbiology and Immunology, University Central Hospital of Tampere, Tampere, Finland

SUMmary The occurrence of IgA class reticulin and endomysium antibodies was examined with the standard immunofluorescence method in coeliac disease and dermatitis herpetiformis. Similar high antibody frequencies were detected in 32 untreated adults $(91 \%)$ and 18 children $(100 \%)$ with coeliac disease and in 14 dermatitis herpetiformis patients with subtotal villous atrophy (reticulin antibodies $93 \%$ and endomysium antibodies $100 \%$ ). The specificity of IgA class reticulin antibodies and endomysium antibodies was high because all 45 adult patients with ulcerative colitis or Crohn's disease, 24 non-coeliac children with abdominal symptoms and 99/100 healthy blood donors were negative for these antibodies. The only positive blood donor had both IgA class reticulin antibodies and endomysium antibodies but also she was found to have coeliac disease. IgA class reticulin antibodies and endomysium antibodies declined in parallel during treatment with a gluten free diet and increased on gluten challenge. This suggests that these antibodies can be used to screen for gluten sensitive enteropathy and to monitor dietary treatment. To characterise the tissue specificity of reticulin antibodies and endomysium antibodies four positive sera were absorbed with human and several rodent liver homogenates. Absorption with rat or other rodent livers removed the rodentspecific reticulin antibodies but not the reticulin antibodies detectable with human tissues or the endomysium antibodies detectable with monkey oeosophagus. These results show that reticulin antibodies can be divided into the rat and human subtypes. The human subtype could not be separated from endomysium antibodies in the present absorption experiments.

Reticulin antibodies frequently occur in the sera of patients with coeliac disease and dermatitis herpetiformis and the $R_{1}$-type of reticulin antibodies have been proposed as a screening test for gluten sensitive enteropathy. ${ }^{1-7}$ In coeliac disease, reported low frequencies $(18 \%-46 \%)$ and low specificity $(75 \%-85 \%)$ of reticulin antibodies seem to mainly concern IgG class. $^{x-12}$ In contrast, IgA class reticulin antibodies seem to be more sensitive and specific. ${ }^{112}$ We pre-

Address for correspondence: $\mathrm{Dr} \mathrm{O}$ Hälström, Department of Clinical Microbiology and Immunology, University Central Hospital of Tampere. SF-33520 Tampere, Finland.

Accepted for publication 19 January 1989. viously found a very high $(97 \%)$ sensitivity and specificity $(98 \%)$ of the IgA class reticulin antibodies in children with coeliac disease,$^{13}$ and a similar high sensitivity in dermatitis herpetiformis patients with subtotal villous atrophy. ${ }^{14}$ is

A new group of connective tissue antibodies, the endomysium antibodies, also determined with immunofluorescence, and recently described by Chorzelski et al, ${ }^{16}$ seem to be closely related to reticulin antibodies. Both reticulin and endomysium antibodies are directed against 'reticulin like', silver stain positive fibres in connective tissues. ${ }^{67}$ Reticulin antibodies are known to react both with human and various rodent tissues. ${ }^{1318}$ Endomysium antibodies, 
in contrast, have been claimed to be more species specific, and react only with the connective tissue (the endomysium) around smooth muscle fibres in the intestinal tract of primates. ${ }^{101 \%} 20$ An almost $100 \%$ sensitivity and specificity has been reported for $\operatorname{IgA}$ class endomysium antibodies in coeliac disease and in dermatitis herpetiformis patients with damaged jejunal mucosa $a^{312.33}$ and endomysium antibodies seem thus to be a new valuable screening test for gluten sensitive enteropathy.

The purpose of this study was to compare the frequencies of $\operatorname{IgA}$ class reticulin antibodies and endomysium antibodies in adults and children with coeliac disease, and in dermatitis herpetiformis patients with normal and damaged jejunal mucosa. Moreover, the specificity of reticulin and endomysium antibodies was examined by using different human and animal tissues as substrates and by performing absorption studies with rodent and human liver homogenates.

\section{Methods}

PATIENTS

COELIAC DISEASE

Sera from 32 untreated adult patients with biopsy proven coeliac disease, mean age 36 years (range 1863 ), were examined. A second serum sample was obtained from four patients who after four to 32 months diet treatment had a normal jejunal mucosa.

Sera from 14 children with flat small intestinal mucosa on their first biopsy were studied comparatively for reticulin antibodies and endomysium antibodies. In all children jejunal mucosa recovered on a gluten free diet but later they will undergo gluten challenge. The mean age was 11 years (range 2-16). Moreover, serum samples were obtained from four children before and after gluten challenge. These children had been on a gluten free diet for five years, had a normal jejunal mucosa, and underwent a two to nine months gluten challenge during which all four developed a flat jejunal mucosa.

DERMATITIS HERPETIFORMIS

Sera from 23 adult dermatitis herpetiformis patients, mean age 38 years (range 18-64), on a normal gluten containing dict were examined. All patients had granular $\operatorname{IgA}$ deposits in the skin, and jejunal biopsy specimens were graded as previously described. ${ }^{1+}$ Fourteen patients had subtotal villous atrophy, five had partial villous atrophy and four slight changes or normal mucosa. A second serum sample was obtained from 10 patients after four to 19 months on a gluten free diet and from eight patients after three to 14 months on a normal diet.
CONTROLS

Control sera were obtained from 24 non-coeliac children, mean age 7.5 years (range 1-15), biopsied for various abdominal symptoms and having a normal jejunal mucosa. Control sera were also obtained from 31 adults with biopsy proven ulcerative colitis, mean age 41 years (range 28-82), from 14 adults with biopsy proven Crohn's disease (four of these had also lesions in proximal small bowel), mean age 39 years (range 20-81), and from 100 healthy blood donors, mean age 41 years (range 20-65). At the time of serum sampling 20 patients with ulcerative colitis and nine with Crohn's disease had signs and symptoms of active disease.

RETICULIN ANDENDOMYSIUM ANTIBODY TESTS Reticulin antibodies and endomysium antibodies were determined with the standard immunofluorescence method using unfixed cryostat $(4 \mu \mathrm{m})$ sections of rat kidney, liver, and stomach for reticulin ${ }^{13}$ and commercial slides of monkey oesophagus sections (SciMedx, Denville, NJ) for endomysium antibodies $^{162-4}$ as antigens. Fluoresceinisothiocyanate (FITC) conjugated antisera against human immunoglobulins were from Kallestad Laboratories (Austin, Texas, USA).

Patient sera were stored from one weck to four years at $-20^{\circ} \mathrm{C}$, and screened for reticulin antibodies and endomysium antibodies at dilutions of $1: 5$ and $1: 10$ with a polyspecific burro antihuman antiserum ( $\mathrm{F} / \mathrm{P}$ molar ratio $2 \cdot 60$, total protein concentration $24.0 \mathrm{mg} / \mathrm{ml}$ ) and a monospecific goat antihuman $\operatorname{IgA}$ antiserum ( $\mathrm{F} / \mathrm{P}$ ratio 2.73 , antibody concentration $1.85 \mathrm{mg} / \mathrm{ml})$. Positive sera were titrated further (1:50, $1: 100,1: 200,1: 500,1: 1000,1: 2000,1: 4000$, and $1: 8000)$ with the goat anti-IgA and anti-IgG antiserum (F/P ratio $2 \cdot 27$, antibody concentration $2 \cdot 48$ $\mathrm{mg} / \mathrm{ml}$ ). All dilutions of sera were made in phosphate buffered saline (PBS) pH 7·2-7·4. Optimal working dilutions of the FITC-labelled antisera (1:80-1:120) were determined by block titration both with reticulin and antinuclear antibody positive sera. Positive and negative controls were included in every batch of tests. Sections were examined on a Leitz Laborlux D epi-illumination fluorescence microscope equipped with an Osram HBO 100 W light source and interference filterblock $\mathrm{I} 2$ for blue light.

All serum samples were examined for $\operatorname{IgA}$ and $\operatorname{IgG}$ class reticulin antibodies and $\operatorname{IgA}$ class endomysium antibodies. Moreover IgG class endomysium antibodies were examined in 20 dermatitis herpetiformis sera, in three cocliac disease sera negative for $\operatorname{Ig} \mathrm{A}$ class reticulin antibodies and endomysium antibodies and in one coeliac disease serum from a patient with IgA deficiency. 

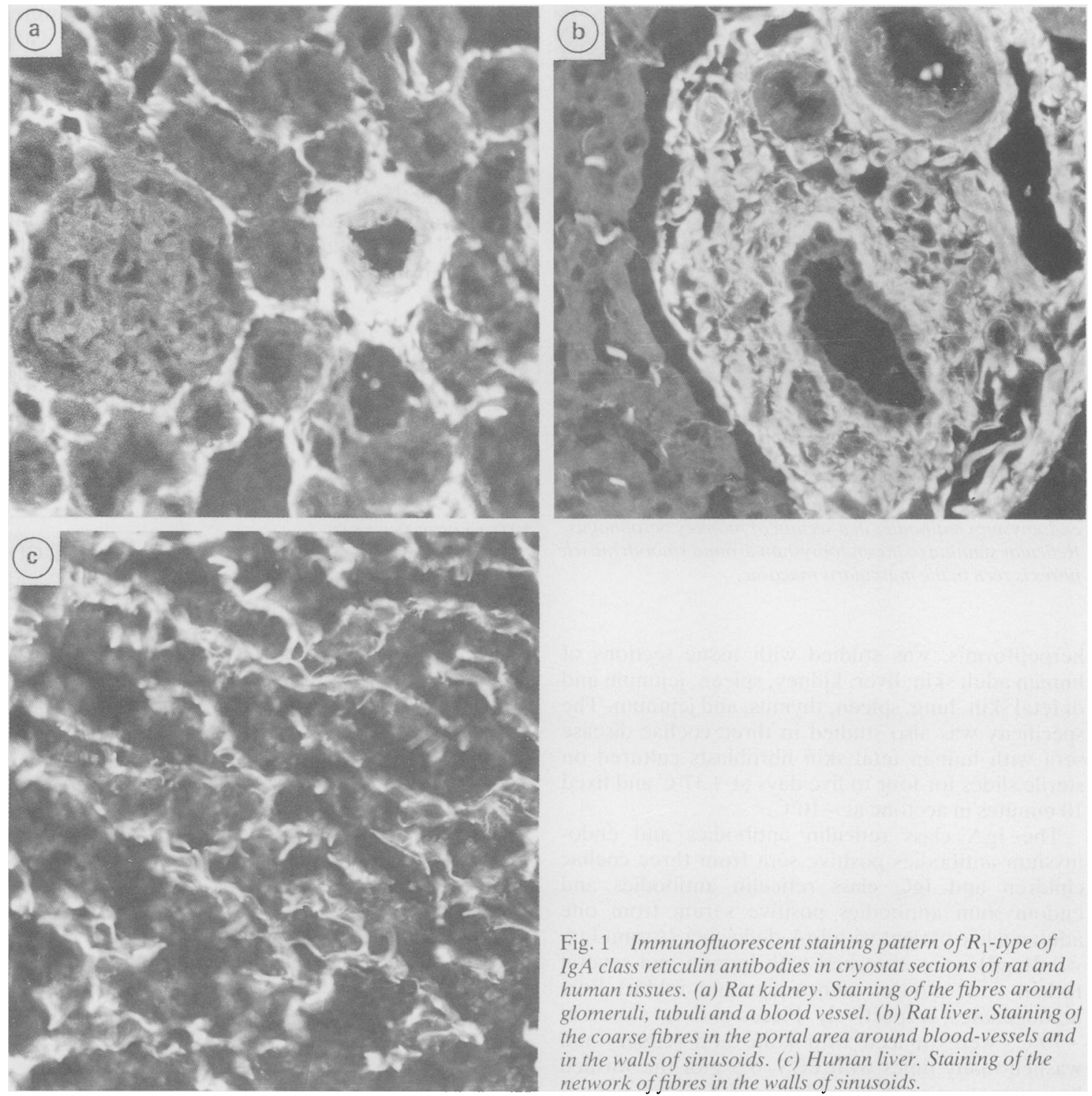

Fig. 1 Immunofluorescent staining pattern of $R_{1}$-type of $\operatorname{Ig} A$ class reticulin antibodies in cryostat sections of rat and human tissues. (a) Rat kidney. Staining of the fibres around glomeruli, tubuli and a blood vessel. (b) Rat liver. Staining of the coarse fibres in the portal area around blood-vessels and in the walls of sinusoids. (c) Human liver. Staining of the network of fibres in the walls of sinusoids.

Specimens were considered reticulin antibody positive, if the characteristic $R_{1}$-type staining pattern was found both in rat liver and kidney sections. ${ }^{1,311}$ $\mathbf{R}_{1}$-pattern included staining of the fibres around the glomeruli and tubuli in the kidney (Fig. 1a), staining of the well defined adventitial fibres around blood vessels in the kidney and liver, staining of the nodular or lumpy fibres in portal areas of the liver (Fig. 1b), and with strong positive sera, staining of discrete, wavy, worm-like strands in the walls of liver sinusoids. The other staining patterns of reticulin antibodies $\left(\mathrm{R}_{\mathrm{s}}, \mathrm{R}_{2}, \mathrm{R}_{\mathrm{ac}}, \mathrm{R}_{\mathrm{kc}}\right)^{\prime}$ in rat tissues, were disregarded. Staining of the endomysium around the smooth muscle fibres in monkey oesophagus was considered as positive for endomysium antibodies (Fig. 2). ${ }^{16} 2+$

TISSUE SPECIFICITY OF RETICULIN AND

ENDOMYSIUM ANTIBODIES

The tissue specificity of reticulin antibodies and endomysium antibodies positive sera from five patients with coeliac disease and two with dermatitis 


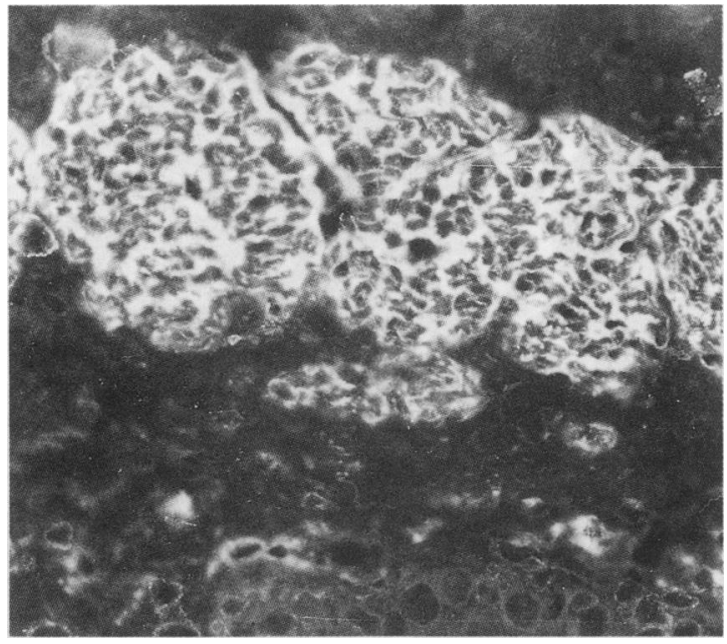

Fig. 2 Immunofluorescent staining pattern of IgA class endomysium antibodies in a section of monkey oesophagus. Reticular staining of the endomysium around smooth muscle fibres is seen in the muscularis mucosae.

herpetiformis, was studied with tissue sections of human adult skin, liver, kidney, spleen, jejunum and of fetal skin, lung, spleen, thymus, and jejunum. The specificity was also studied in three coeliac disease sera with human fetal skin fibroblasts cultured on sterile slides for four to five days at $+37^{\circ} \mathrm{C}$ and fixed 10 minutes in acetone at $-10^{\circ} \mathrm{C} . .^{25}$

The IgA class reticulin antibodies and endomysium antibodies positive sera from three coeliac children and $\operatorname{IgG}$ class reticulin antibodies and endomysium antibodies positive serum from one adult coeliac patient with IgA-deficiency (serum $\operatorname{IgA}$ $<0.01 \mathrm{~g} / \mathrm{l}$ ) were absorbed with human and several rodent (rat, mouse, guinea-pig, and rabbit) liver homogenates, respectively. Pieces of liver, stored at $-70^{\circ} \mathrm{C}$, were minced with knife and scissors and washed many times with PBS. $0 \cdot 5 \mathrm{~g}$ of the washed homogenate was then added to $4.5 \mathrm{ml}$ of patient serum (diluted 1:100 with PBS), mixed two hours at room temperature in a cell mixer, centrifuged $60 \mathrm{~min} /$ $3000 \mathrm{~g}$ at $+10^{\circ} \mathrm{C}$ and absorbed once more with a further $0.5 \mathrm{~g}$ of liver homogenate and left to stand overnight at $+4^{\circ} \mathrm{C}$ before centrifugation. Supernatants were stored at $-20^{\circ} \mathrm{C}$ until studied. To recover the antibodies from the liver homogenates, $4.5 \mathrm{ml}$ of $0.1 \mathrm{M}$ citrate buffer ( $\mathrm{pH} 3.0)$ was added to $0.5 \mathrm{~g}$ of homogenate, mixed $10 \mathrm{~min}$ in the cell mixer, centrifuged $60 \mathrm{~min} / 3000 \mathrm{~g}$ at $+10^{\circ} \mathrm{C}$ and the supernatants dialysed overnight against 11 of PBS at room temperature, centrifuged again as before and stored at $-20^{\circ} \mathrm{C}$ until studied. Reticulin antibodies and endomysium antibodies concentrations were measured in the absorbed and eluted sera with several rat and human tissues and with monkey oesophagus.

\section{GLIADIN ANTIBODIES}

Gliadin antibodies were measured with a microELISA method as previously described. ${ }^{26} \operatorname{IgA}$ gliadin antibody concentrations over $0.2 \mathrm{EU} / \mathrm{ml}$ (arbitary ELISA unit) and IgG-gliadin antibody concentrations over $5 \mathrm{EU} / \mathrm{ml}$ were considered positive.

\section{STATISTICAL ANALYSIS}

The effect of the diet treatment on the antibody levels was analysed with Wilcoxon's matched-pairs signedranks test.

\section{Results}

COELIAC DISEASE

Twenty nine $(91 \%)$ of the 32 untreated adult CD patients had positive IgA-reticulin antibodies and IgA-endomysium antibodies and 14 (44\%) had IgGreticulin antibodies (Table 1, Fig. 3). The three patients with negative IgA class reticulin antibodies and endomysium antibodies had IgG class reticulin antibodies (titres $1: 100$ to $1: 8000$ ) and endomysium antibodies (titres $>1: 500$, the endpoint could not be discerned). One of these patients had IgA deficiency $(\operatorname{IgA}<0.01 \mathrm{~g} / \mathrm{l})$. All three patients responded to gluten free diet and after one to two years all had normal jejunal mucosa and no IgG class reticulin antibodies or endomysium antibodies could be found.

Table 1 Frequency of $\operatorname{Ig} A$ class reticulin $(\operatorname{Ig} A-R A)$ and endomysium ( $\operatorname{Ig} A-E m A)$ antibodies in patients with untreated gluten sensitive enteropathy and in controls.

\begin{tabular}{|c|c|c|c|}
\hline & $\begin{array}{l}\text { Number of } \\
\text { patient } \\
\text { sera }\end{array}$ & $\begin{array}{l}\text { Positive } \\
\operatorname{Ig} A-R A\end{array}$ & $\begin{array}{l}\text { Positive } \\
\operatorname{Ig} A-E m A\end{array}$ \\
\hline \multicolumn{4}{|l|}{ Patients: } \\
\hline $\begin{array}{l}\text { Coeliac disease: } \\
\text { adults }\end{array}$ & 32 & $29(91 \%)$ & $29(91 \%)$ \\
\hline children & $18^{*}$ & $18(100 \%)$ & $18(100 \%)$ \\
\hline Dermatitis herpetiformis & $14 t$ & $13(93 \%)$ & $14(100 \%)$ \\
\hline $\begin{array}{l}\text { Non-coeliac children with } \\
\text { normal mucosa }\end{array}$ & 24 & 0 & () \\
\hline \multicolumn{4}{|l|}{ Controls: } \\
\hline Ulcerative colitis & 31 & 0 & () \\
\hline Crohn's disease & 14 & () & 0 \\
\hline Blood donors & 100 & $1(1 \%)$ & $1(1 \%)$ \\
\hline
\end{tabular}

*Includes four sera obtained during gluten challenge: †Includes only patients with subtotal villous atrophy. 


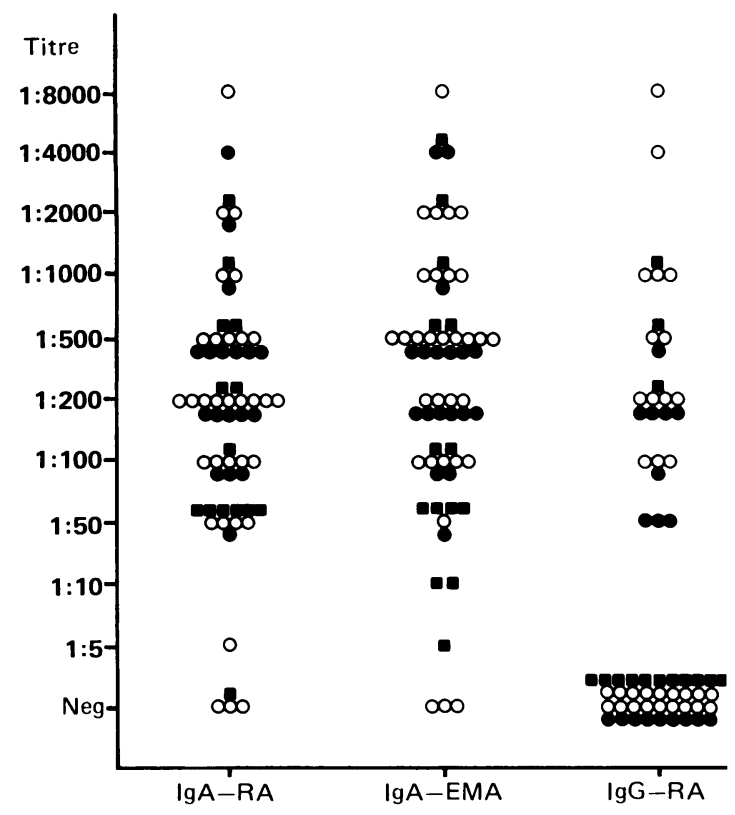

Fig. 3 Titres of $\operatorname{Ig} A$ class reticulin ( $\lg A-R A), \operatorname{Ig} A$ class endomysium ( $\operatorname{Ig} A-E M A)$, and $\operatorname{Ig} G$ class reticulin $(\operatorname{Ig} G-R A)$ antibodies in the sera of 32 adults $(O)$ and 18 children $(O)$ with coeliac disease and in 14 dermatitis herpetiformis patients with subtotal villous atrophy (ם).

All 14 children with untreated coeliac disease and the four children challenged with gluten had positive IgA class reticulin antibodies and endomysium antibodies and nine $(50 \%)$ were positive in IgG-reticulin antibodies (Table 1, Fig. 3).

\section{DERMATITIS HERPETIFORMIS}

Nineteen $(83 \%)$ of the 23 dermatitis herpetiformis patients had positive IgA class reticulin antibodies (titres 1:10-1:2000) and endomysium antibodies (titres 1:5-1:4000). Seventeen patients had both tests positive; one patient had only reticulin antibodies (1:10) and one only endomysium antibodies (1:5). Thirteen $(93 \%)$ of the 14 dermatitis herpetiformis patients with SVA had IgA class reticulin antibodies, $14(100 \%)$ had endomysium antibodies and three $(13 \%)$ had IgG class reticulin antibodies (Table 1, Fig. 3). Three of the five dermatitis herpetiformis patients with partial villous atrophy had both $\operatorname{IgA}$ reticulin antibodies (titres 1:10-1:100) and IgAendomysium antibodies (titres 1:50-1:200) and three of the four dermatitis herpetiformis patients with slight changes or normal mucosa had IgA class reticulin antibodies (titres $1: 10$ ) and two $\operatorname{Ig} A$ class endomysium antibodies (titres 1:10 and 1:50). None of the 20 dermatitis herpetiformis sera studied for IgG-endomysium antibodies were positive.
CONTROLS

No IgA class reticulin antibodies or endomysium antibodies or $\mathrm{IgG}$ class reticulin antibodies were found in control patients (Table 1). One (1\%) blood donor had both IgA-reticulin antibodies (titre 1:200) and $\operatorname{IgA}$-endomysium antibodies (titre $1: 200)$. This 38 year old woman had experienced slight abdominal symptoms for several years. A jejunal biopsy was performed and it revealed subtotal villous atrophy. She responded clinically and serologically to gluten free diet confirming that she had cocliac disease.

EFFECT OF GLUTEN FREE DIET AND GLUTEN CHALLENGE ON RETICULIN ANTIBODIES AND ENDOMYSIUM ANTIBODIES

Four adult patients with coeliac disease and 10 with dermatitis herpetiformis were followed four to 32 months on a gluten free diet. The concentrations of IgA class reticulin antibodies and endomysium antibodies declined in parallel in both patient groups (Fig. 4) and the decrease was significant $(p<0 \cdot 01)$ both for IgA class reticulin antibodics and endomysium antibodies. In the coeliac disease group the antibodies were negative after four to 12 months on the diet except in one patient who showed low (1:10) IgA-endomysium antibodies titre after five months. In dermatitis herpetiformis group low positive (1:101:50) IgA-reticulin antibodies titres were found in three patients after six to 12 months and $\operatorname{lgA}$ endomysium antibodies titres $(1: 5-1: 50)$ in five patients after four to 12 months on a gluten free diet. Six of eight dermatitis herpetiformis patients who were followed for three to 14 months on a normal diet had low titres of IgA-reticulin antibodies and five of these had IgA-endomysium antibodies (titres $1: 10$ $1: 50)$ at the beginning and at the end of the follow up. Two antibody negative dermatitis herpetiformis patients developed both IgA-reticulin antibodies (1:10) and IgA-endomysium antibodies (1:10) during the follow up.

All four antibody negative coeliac children became IgA-reticulin antibodies and IgA-endomysium antibodies positive (titres 1:500-1:4000) when challenged with gluten and one became also IgGreticulin antibodies $(1: 200)$ positive.

TISSUE SPECIFICITY OF RETICULIN AND

ENDOMYSIUM ANTIBODIES

All seven sera reacted with reticulin fibres in all human tissues studied and the $\operatorname{IgA}$ and $\operatorname{IgG}$ class reticulin antibodies gave identical stainings. The fluorescence was intense in the fetal lung, thymus, and jejunum; clear in the adult liver, spleen, and jejunum but weak in the adult skin and kidney. The staining in human liver was most specific on the fibres in the walls of the sinusoids (Fig. 1c) but not in the 

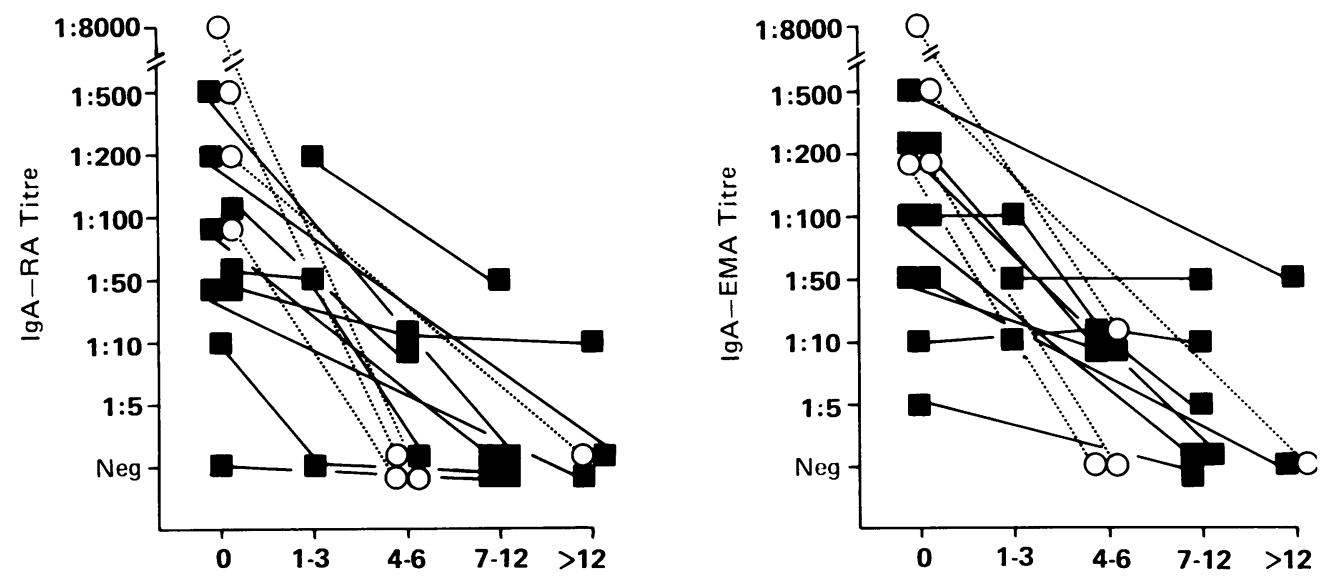

Months on gluten free diet

Fig. 4 The effect of gluten-free diet treatment on $\operatorname{Ig} A$ class reticulin $(R A)$ and endomysium (EmA) antibodies in four adult patients with coeliac disease $(\bigcirc)$ and in 10 dermatitis herpetiformis patients with subtotal or partial villous atrophy (ם).

portal area as seen in rat liver. A reticular staining was also seen in the cytoplasm around the nucleus in some but not in all cultured human fibroblasts.

After absorptions of sera with rodent (rat, mouse, guinea pig, and rabbit) liver homogenates $\operatorname{IgA}$ or IgG class reticulin antibodies could not any more be detected with rodent tissues but human tissues, fibroblasts and monkey oesophagus gave a clear $\mathrm{R}_{1^{-}}$ type reticulin antibodies staining (Table 2). In contrast, after absorption with human liver homogenates both rat and human tissues, fibroblasts and monkey oesophagus all gave negative results. These absorptions had no effect on IgA or IgG class gliadin antibody concentrations.

The $\operatorname{IgA}$ and $\operatorname{IgG}$ class reticulin antibodies and endomysium antibodies eluted from rodent liver homogenates reacted predominantly with rat but only weakly with human and monkey tissues. In contrast, the antibodies eluted from human liver homogenates reacted strongly with all human and rodent tissues, fibroblasts, and monkey oesophagus.

\section{Discussion}

The present study confirms the importance of $\operatorname{IgA}$ class antibody measurements in coeliac disease and dermatitis herpetiformis. Similar high frequencies $(91 \%-100 \%)$ of IgA class reticulin and endomysium antibodies were found in untreated adults and children with coeliac disease and in dermatitis herpetiformis patients with subtotal villous atrophy. The specificities of these two IgA antibody tests were also high because none of the 69 disease controls and only one of the 100 blood donors had these antibodies. In agreement with the present results, Seah $e t$ $a l^{5}$ reported $\operatorname{IgA}$ class reticulin antibodies in nine of

Table 2 Serum titres of $I g A$ class reticulin $(R A)$ and endomysium (EmA) antibodies before and after absorption with rat and human liver homogenates in three untreated coeliac children. Reticulin antibodies were measured with rat kidney and human liver and EmA with monkey oesophagus tissue sections by using standard immunofluorescence methods and monospecific antihuman IgA-conjugate

\begin{tabular}{|c|c|c|c|c|c|c|c|c|c|}
\hline \multirow{4}{*}{$\begin{array}{l}\text { Case } \\
\text { no }\end{array}$} & & & & \multicolumn{6}{|c|}{ After absorption } \\
\hline & \multicolumn{3}{|c|}{ Before absorption } & \multicolumn{3}{|c|}{ With rat liver } & \multicolumn{3}{|c|}{ With human liver } \\
\hline & \multicolumn{2}{|l|}{$R A$} & \multirow{2}{*}{$\begin{array}{l}\text { EmA } \\
\text { monkey } \\
\text { oesophagus }\end{array}$} & \multicolumn{2}{|l|}{$R A$} & \multirow{2}{*}{$\begin{array}{l}\text { EmA } \\
\text { monkey } \\
\text { oesophagus }\end{array}$} & \multicolumn{2}{|l|}{$R A$} & \multirow{2}{*}{$\begin{array}{l}\text { EmA } \\
\text { monkey } \\
\text { oesophagu. }\end{array}$} \\
\hline & Rat kidney & Human liver & & Rat kidney & Human liver & & Rat kidney & Human liver & \\
\hline 1 & $2000)$ & 20000 & $40(0)$ & $\mathrm{NEG}^{*}$ & 1000 & 2000 & NEG & NEG & NEG; \\
\hline 2 & 1000 & 1000 & 500 & NEG & 200 & $5(x)$ & NEG & NEG & NEG \\
\hline 3 & $2000)$ & 4000 & 1000 & NEG & 1000 & 500 & NEG & NEG & NEG \\
\hline
\end{tabular}

*Negative titre $<1: 100$. 
$10(90 \%)$ and Mallas et al ${ }^{\prime \prime}$ in $13 / 17(76 \%)$ untreated children with coeliac disease. Moreover, Eade et $\mathrm{al}^{12}$ found $\operatorname{IgA}$ class reticulin antibodies in $22 / 28(79 \%)$ children and adults with coeliac disease, and Ljunghall et $l^{27}$ in four of $10(40 \%)$ and Volta et $l^{2 \mathrm{x}}$ in four of $16(25 \%)$ adult dermatitis herpetiformis patients with subtotal villous atrophy. In all these studies the frequencies of IgG class reticulin antibodies have been the same or lower than IgA class reticulin antibodies and all sera from healthy and disease controls, including patients with ulcerative colitis and Crohn's disease, have been negative for IgA-reticulin antibodies.

High prevalence of IgA class endomysium antibodies $(65 \%-100 \%)$ have been reported in coeliac disease and dermatitis herpetiformis recently by Chorzelski, Beutner, and coworkers. ${ }^{17142112}$ The simultaneous occurrence of IgA class endomysium antibodies and reticulin antibodies has been previously reported only in dermatitis herpetiformis patients ${ }^{17}$ but in contrast with the present study the frequency of IgA class reticulin antibodies $(25 \%)$ was clearly lower than that of endomysium antibodies $(65 \%)$. One reason for this difference could be that Kumar $e t a l^{17}$ used only mouse kidney sections in reticulin antibodies test and not a composite block of rat tissues (kidney, liver, and stomach) as was used in the present and in two recent screening studies ${ }^{20.30}$ detecting a high $(93 \%$ and $83 \%$ ) prevalence of reticulin antibodies in coeliac disease.

The present absorption studies showed that the rodent-specific IgA and IgG class antibodies could be absorbed with rodent liver homogenates. After these absorptions, however, a strong positivity against all human tissues and monkey oesophagus persisted. This positivity was regarded as a human (or primates) subtype of reticulin antibodies and interestingly, when this subtype was absorbed away with human liver homogenates also endomysium antibodies disappeared. Therefore, the present absorption experiments did not disclose any differences between endomysium antibodies and human subtype of reticulin antibodies. Unfortunately, enough monkey oesophagus tissue was not available to confirm that absorption with this tissue also removes human subtype of reticulin antibodies. $\mathrm{R}_{1}$-type of reticulin antibodies reacting with human liver ${ }^{51 x}$ and spleen ${ }^{2}$ has also been described previously and already Seah et $a l^{5}$ and Eterman $e a^{31}$ showed that such antibodies can react with human jejunum, a finding recently confirmed also by Karpati et al. ${ }^{32}$

In conclusion, the present study showed the usefulness of IgA class reticulin and endomysium antibody tests in detecting gluten sensitive enteropathy and monitoring dietary treatment in patients with coeliac disease and dermatitis herpetiformis. Two subtypes of reticulin antibodies were characterised by absorption studies, the first subtype reacting with rodent tissues and the second also with human tissues. The human subtype of reticulin antibodies seems to be very similar to endomysium antibodies but more detailed experiments are needed to confirm their identity.

I wish to express my thanks to Drs Timo Reunala, Markku Mäki, Olavi Keyriläinen, and Pekka Collin for patient serum samples, Finnish Red Cross for blood donor sera, and Dr Markku Viander for examining gliadin antibodies. Mrs Pirjo Saariaho, Riitta Huttunen, and Sairi Koskinen are acknowledged for their skilful technical assistance. This study was supported by a grant from the Emil Aaltonen Foundation.

\section{References}

1 Rizzetto M, Doniach D. Types of 'reticulin' antibodies detected in human sera by immunofluorescence. $J$ Clin Pathol 1973; 26: 841-51.

2 Williamson N, Asquith P, Stokes PL, Jowett AW, Cooke WT. Anticonnective tissue and other antitissue 'antibodies' in the sera of patients with cocliac disease compared with the finding in a mixed hospital population. J Clin Pathol 1976; 29: 484-94.

3 Seah PP, Fry L, Hoffbrand AV, Holborow EJ. Tissue antibodies in dermatitis herpetiformis and adult cocliac discase. Lancet 1971; i: 834-6.

4 Alp MH, Wright R. Autoantibodies to reticulin in patients with idiopathic steatorrhoea, coeliac disease. and Crohn's disease and their relation to immunoglobulins and dietary antibodies. Lancet 1971; ii: 682-5.

5 Seah PP, Fry LL, Rossiter MA, Hoffbrand AV, Holborow EJ. Anti-reticulin antibodies in childhood coeliac discase. Lancet 1971; ii: 681-2.

6 Magalhaes AF, Peters TJ, Doe WF. Studies on the nature and significance of connective tissue antibodies in adult cocliac disease and Crohn's disease. Gut 1974; 15: 284-8.

7 Stevens FM, Lloid R, Egan-Mitchell B, et al. Reticulin antibodies in patients with cocliac disease and their relatives. Gut 1975; 16: 598-6(02.

8 Seah PP, Fry LL, Holborow EJ, et al. Antireticulin antibody: Incidence and diagnostic significance. Gut 1973; 14: 311-5.

9 Dias J, Unsworth DJ, Walker-Smith JA. Antigliadin and antireticulin antibodies in screening for cocliac discase. Lancet 1987; ii: 157-8.

10) Volta U, Bonazzi C, Pisi E, Salardi S, Cacciari E. Antigliadin and antireticulin antibodies in cocliac disease and at onset of diabetes in children. Lancet 1987; ii: 1034 .

11 Mallas EG, Williamson N. Cooper BT. Cooke WT. IgA class reticulin antibodies in relatives of patients with coeliac discase. Gut 1977; 18: 647-50.

12 Eade OE, Lloyd RS, Lang C. Wright R. IgA and IgG 
reticulin antibodies in cocliac and non-cocliac patients. Gut 1977; 18: 991-3.

13 Mäki M, Hällström O, Vesikari T, Visakorpi JK. Evaluation of a serum IgA-class reticulin antibody test for the detection of childhood celiac discase. J Pediatr 1984; 105: 901-5.

14 Hällström $\mathrm{O}$, Reunala $\mathrm{T}$. IgA class reticulin antibodies in dermatitis herpetiformis: A good indicator of jejunal damage. Acta Derm Venereol (Stockh) 1985; 65: 330-2.

15 Vainio E, Kosnai I, Hällström O, Karpati S, Mäki M, Reunala T. Antigliadin and antireticulin antibodies in children with dermatitis herpetiformis. J Pediatr Gastroenterol Nutr 1986; 5: 735-9.

16 Chorzelski TP, Sulcj J, Tchorzewska H, et al. IgA class endomysium antibodies in dermatitis herpetiformis and cocliac discase. Ann NY Acad Sci 1983; 420: 325-34.

17 Kumar V, Hemedinger E, Chorzelski TP, et al. Reticulin and endomysial antibodies in bullous diseases. Arch Dermatol 1987; 123: 1179-82.

18 Lazzari R, Volta U, Bianchi BF, Collina, Pisi E. R1 reticulin antibodies: Markers of celiac disease in children on a normal diet and on gluten challenge. J Pediatr Gastroenterol Nutr 1984; 3: 516-22.

19 Chorzelski TP, Beutner EH, Sulcj J, et al. IgA antiendomysium antibody. A new immunological marker of dermatitis herpetiformis and cocliac disease. $\mathrm{Br} J$ Dermatol 1984; 111: 395-402.

20) Kapuscinska A, Zalewski T, Chorzelski TP, et al. Disease specificity and dynamics of changes in $\operatorname{IgA}$ class anti-endomysial antibodies in celiac disease. $J$ Pediatr Gastroenterol Nutr 1987; 6: 529-34.

21 Lconard JN, Chorzelski TP, Beutner EH, et al. IgA antiendomysial antibody detection in the serum of patients with dermatitis herpetiformis following gluten challenge. Arch Dermatol Res 1985; 277: 349-51.

22 Bcutner EH, Chorzelski TP, Kumar V, Leonard J, Krasny S. Sensitivity and specificity of $\operatorname{IgA}$-class antiendomysial antibodies for dermatitis herpetiformis and findings relevant to their pathogenic significance. $\mathrm{J} \mathrm{Am}$ Acad Dermatol 1986; 15: 464-73.

23 Accetta PM, Kumar VP, Beutner EH, Chorzelski TP, Helm FM. Anti-endomysial antibodies. A serologic marker of dermatitis herpetiformis. Arch Dermatol 1986; 122: 459-62.

24 Kumar V, Beutner EH, Chorzelski TP. Distribution of monkey esophagus antigens reactive with $\operatorname{lgA}$-class antibodies in the sera of dermatitis herpetiformis patients. Arch Derm Res 1984; 276: 293-6.

25 Unsworth DJ, Scott DL, Almond TJ, Bcard HK, Holborow EJ, Walton KW. Studies on Reticulin. I: Serological and immunohistological investigation of the occurrence of collagen type III, fibronectin and the noncollagenous glycoprotein of Pras and Glynn in reticulin. Br J Pathol 1982; 63: 154-66.

26 Vainio E, Kalimo K. Reunala T, Viander M, Palosuo T. Circulating IgA- and IgG-class antigliadin antibodics in dermatitis herpetiformis detected by enzyme-linked immunosorbent assay. Arch Dermatol Res 1983; 275: 15-8.

27 Ljunghall K, Lööf L, Grimelius L, Forsum U, Jonsson J, Scheynius A, Schilling W. Dermatitis herpetiformis: Relation between circulating antibodies against reticulin and gluten, small-intestinal mucosal status and absorptive capacity. Acta Derm Venereol (Stockh) 1983; 63: 27-34.

28 Volta U, Cassani F, DeFrancis R, et al. Antibodies to gliadin in adult coeliac disease and dermatitis herpetiformis. Digestion 1984; 30: 263-70.

29 Auricchio S, Mazzacca G, Tosi R, Visakorpi J, Mäki M, Polanco I. Cocliac discase as a familial condition: Identification of asymptomatic cocliac patients within family groups. Gastroenterol Int 1988; 1: 25-31.

30 Khoshoo V, Bhan MK, Unsworth DJ, Kumar R Walker Smith JA. Anti-reticulin antibodies: Useful adjunct to histopathology in diagnosing celiac disease especially in a developing country. $J$ Pediatr Gastroenterol Nutr 1988; 7: 864-6.

31 Eterman KP, Feltkamp TEW. Antibodies to gluten and reticulin in gastrointestinal diseases. Clin Exp Immunol 1978; 31: 92-9.

32 Karpati SM, Török EM, Kosnai IM. IgA class antibody against human jejunum in sera of children with dermatitis herpetiformis. J Invest Dermatol 1986; 87: 703-6. 